\title{
DIAN-TU ARGENTINA
}

\section{A great human story of a small group of people DIAN-TU ARGENTINA}

\section{Una gran historia humana de un pequeño grupo de personas}

\section{Patricio Chrem-Mendez ${ }^{1}$ \\ Pablo Bagnati ${ }^{1}$}

How to cite this article:

Chrem-Mendez, P. \& Bagnati, P. (2021). DIAN-TU ARGENTINA. A great human story of a small group of people. Journal of Applied Cognitive Neuroscience, 2(1), e00173805.

https://doi.org/10.17981/JACN.2.1.2021.05

Manuscript received on 11th April 2021 Accepted on 13th June 2021

\begin{abstract}
Alzheimer's disease is, by far the first, cause of dementia and the more frequent neurodegenerative disease. Considered as a result of multifactorial causes, aging is the main risk factor for the classical form of the disease and because of global aging, a very significant increase in the prevalence is expected in the upcoming decades, especially in countries in development. Several drugs with different targets have been tried so far and, still with no success. Frenzied efforts seeking a new disease-modifying drug are constantly being pursued and innovative models of the clinical trials have emerged. The DIAN initiative studies individuals with known mutations in the deterministic genes of the disease. Autosomal Dominantly Alzheimer Disease (ADAD) showed to be a more predictable model in terms of whom and when will get the disease. This allows testing novel therapeutics agents by choosing the drug according to the biological moment of the disease. But ADAD is also a uniquely human story full of courage and hope. The DIAN trial has started in Argentina and a new anti-tau age has begun as well.
\end{abstract}

Keywords: DIAN-TU Argentina; ADAD; anti-tau; Taco Pozo; FLENI

Resumen

La enfermedad de Alzheimer es por mucho, la primera causa de demencia y la enfermedad neurodegenerativa más frecuente. Considerada como resultado de causas multifactoriales, el envejecimiento sigue siendo el principal factor de riesgo en su forma clásica y debido al envejecimiento global, se espera un aumento muy significativo de la prevalencia en las próximas décadas, especialmente en los países en desarrollo. Hasta ahora se han probado numerosos fármacos con diferentes dianas aunque aún sin éxito. Constantemente se realizan descomunales estudios en busca de un nuevo fármaco que logre modificar el destino de la enfermedad y así han surgido innovadores modelos de ensayos clínicos. La iniciativa DIAN estudia individuos con mutaciones conocidas en los genes determinantes de la enfermedad. La enfermedad de Alzheimer autosómica dominante (ADAD) demostró ser un modelo más predecible en términos de quién y cuándo contraerá la enfermedad. Esto permite probar nuevos agentes terapéuticos eligiendo el fármaco según el momento biológico de la enfermedad. Pero ADAD es también una historia muy humana llena de coraje y esperanza. El ensayo DIAN ha comenzado en Argentina y también ha comenzado una nueva era anti-tau.

Palabras clave: DIAN-TU Argentina; ADAD; antitau; Taco Pozo; FLENI

${ }^{1}$ Memory Center, FLENI, Buenos Aires City, Argentina.

Contact mail: pchremmendez@fleni.org.ar 
For more than a decade (2010), the DIAN [Dominantly Inherited Alzheimer Network] led by the Washington University School of Medicine in St. Louis, USA, and mostly funded by the National Institutes of Health (NIH), the Alzheimer's Association, and donations from philanthropic funds, have embarked on a multinational effort to better understand Alzheimer's disease (AD) and test novel potential treatments (Morris et al., 2012). In this case, this aim is pursued on the study of a particular and minority group within $\mathrm{AD}$, such as autosomal dominant Alzheimer Disease (ADAD). DIAN studies families with mutations in the deterministic genes of AD (PS1, PS2, and APP), named in such a way because they guarantee that those who inherit the mutations will develop the disease at an early age (average 45 years, range 30 to 60 years) and with a chance close to $100 \%$ (complete penetrance). In general, these individuals, due to their youth, do not present any other health problems. Another distinctive feature is that the estimated age of onset is maintained with very little variation between generations. Both conditions provide something very difficult to obtain in medicine, which is: absolute predictability of who will develop the disease and, even more, when it will develop. From there arises the scientific and unique importance that this minority of cases of ADAD constitute. In other words, the ADAD represents the purest and most predictable model of AD.

But it is precisely these peculiar characteristics that generate a real drama in families when it is found some of the deterministic mutations of ADAD. As if suffering from $\mathrm{AD}$ were not enough, it is much more dramatic to have it at an early age in life, fully productive; having seen it happen in parents, uncles, grandparents; with the risk of having transmitted it to their children (50\% risk); and living each year as a true countdown. In this sense, ADAD also represents the paradigm of dominant genetic disease and a real challenge for genetic counseling (Rahman et al., 2012; Aschenbrenner et al., 2020).

Currently, the DIAN is divided into three main lines of research: the DIAN Obs (observational) was the pivotal study (2010) and is dedicated to investigating, in the most exhaustive possible manner, mutation-carriers, comparing them with non-carriers. The study is carried out in a series of visits with a frequency established according to the age of the individual and the difference the participant has with its parent's age at onset. Cognitive evaluations, DNA and RNA extractions, cell immortalization, plasma, CSF, MRI, PET with PIB, FDG, and TAU are carried out. In the "Obs", both those who learnt their genetic status and those who know they are not carriers (and therefore do not have any risk) are allowed to participate, the latter functioning as a control group. It is, in any case, the vocation of the participants to contribute to science some degree of knowledge, the main reason for which they enroll. This line of study has already been followed for 11 years and has revealed important findings in terms of novel biomarkers (in CSF and blood) of $\mathrm{AD}$, at the same time that it has ratified the same sequence of molecular events as in the Classic form of AD (Bateman et al., 2012; Bateman et al., 2011). 
The DIAN TU (intervention unit, from English: "trial unit"), started in 2012, is intended to test new potential treatments. It has a dynamic design in order to test the cohort with the best possible treatment. In general, it is proposed to test more than one drug at the same time in different branches in parallel and its arms were projected until 2028 (Bateman et al., 2017). The "TU" has also been split into primary preventive or secondary preventive based on the time before the estimated age of onset. By doing so, different drug mechanisms could be tested according to the biological moment of the disease. Naturally, this DIAN line is the one that generates the greatest hope in the participants and their families. Only carriers participate (whether or not they know their genetic status) and non-carriers who do not know their genetic status. At the beginning of 2020, the results of the first two arms were announced, which began in 2012 with very encouraging results at the biomarker level for the anti-amyloid antibody gantenerumab (arm II of the TU). For this reason, gantenerumab has entered in an open phase branch (open-labeled extension). But only the participants of that first trial were included. Two more arms, solanezumab (arm I) and atabecestat (arm III) did not progress further or were suspended due to lack of effectiveness or adverse effects. Now (2021), a new test arm (IV) was announced with an anti-Tau antibody specific for the mid-region and microtubule-binding sites (E2814).

Finally, there is a third line which is the DIAN EXR, whose main function is to spread information and invite new families to participate through a digital registry that allows direct communication between family members and researchers.

In Argentina, the DIAN Obs began its enrollment in the FLENI institute in December 2014 under the national subsidy PICT2015-2110. To date, 11 participants from 6 families with 5 different mutations have been enrolled. Of these, 9 are currently in progress ( 1 withdrawal and 1 deceased) and a total of 28 in-person visits have been made. In 2018, FLENI had been assigned the possibility of entering DIAN TU arm III, but as mentioned, this branch was suspended at the time.

Meanwhile, between 2018 and 2019 as part of DIAN EXR, a team of researchers from FLENI, together with doctors from Salta, moved to the city of Taco Pozo, Province of Chaco, since a large branch of a family of Buenos Aires resides there. This family branch consists of approximately 50 individuals, 21 of them donated blood and it was determined that half of them are carriers (Figure 1). Later, on a second trip, the same team traveled to Paraná, Entre Ríos province, together with doctors from the San Martin Hospital in search of families of Volga German descent (Russian Germans), known to have a specific mutation in PSEN2. With such a large community located in Argentina, fieldwork was carried out. After interviewing 20 families, the finding was confirmed in one of them and there are two more highly suspicious (Figure 2).

The incorporation of these families who are in other provinces represents a logistical and resource challenge. Because of this, the DIAN central committee has requested new international grants for the expansion of DIAN in Latin America. This time the Alzheimer's Association has allocated 1 million dollars for the opening of new sites in Mexico, Colombia, Brazil, and an additional site in Argentina (Libre-Guerra et al., 2020). The latter will be located in the Province of Salta, Argentina and it will work out as a satellite center for FLENI to carry out the observational study. 


\section{Satellite Site, "Salta-Taco Pozo"}
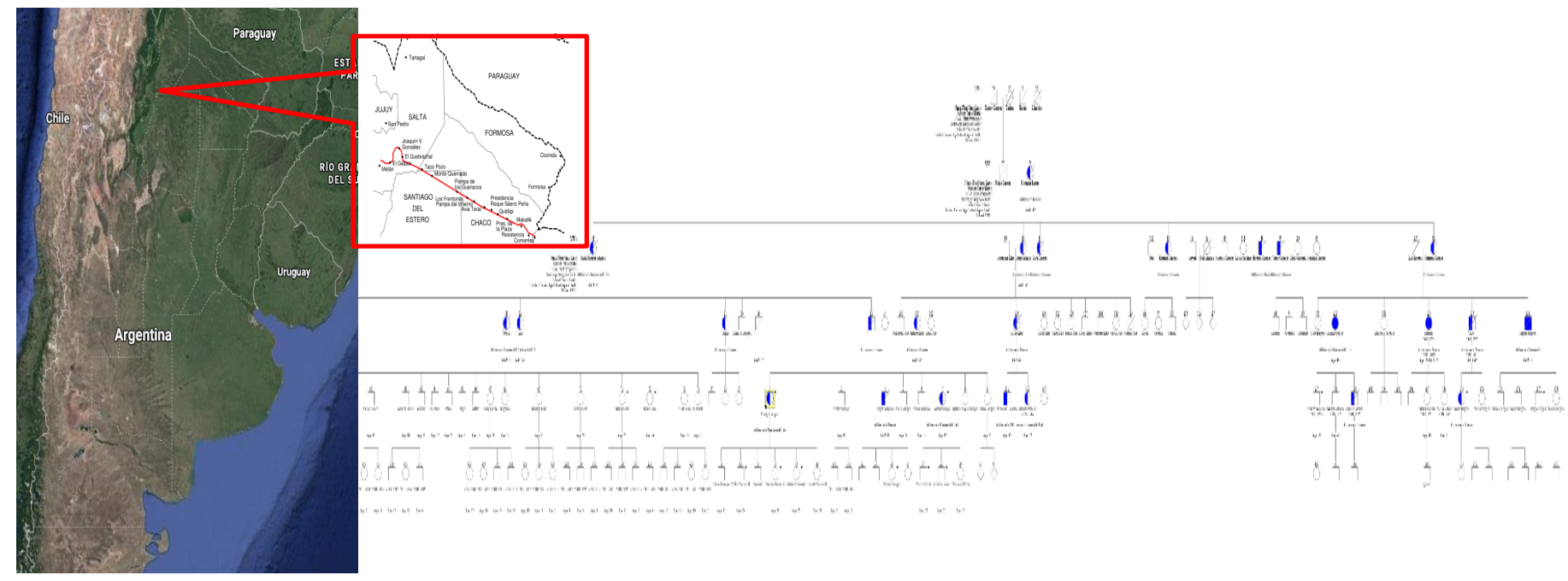

Figure 1. Shows next satellite site opened in Argentina as part of DIAN LatAm initiative, and the pedigree of the family founded in this location as part of the DIAN EXR.

Source: Authors.

\section{DIAN EXR-Arg Entre Ríos}

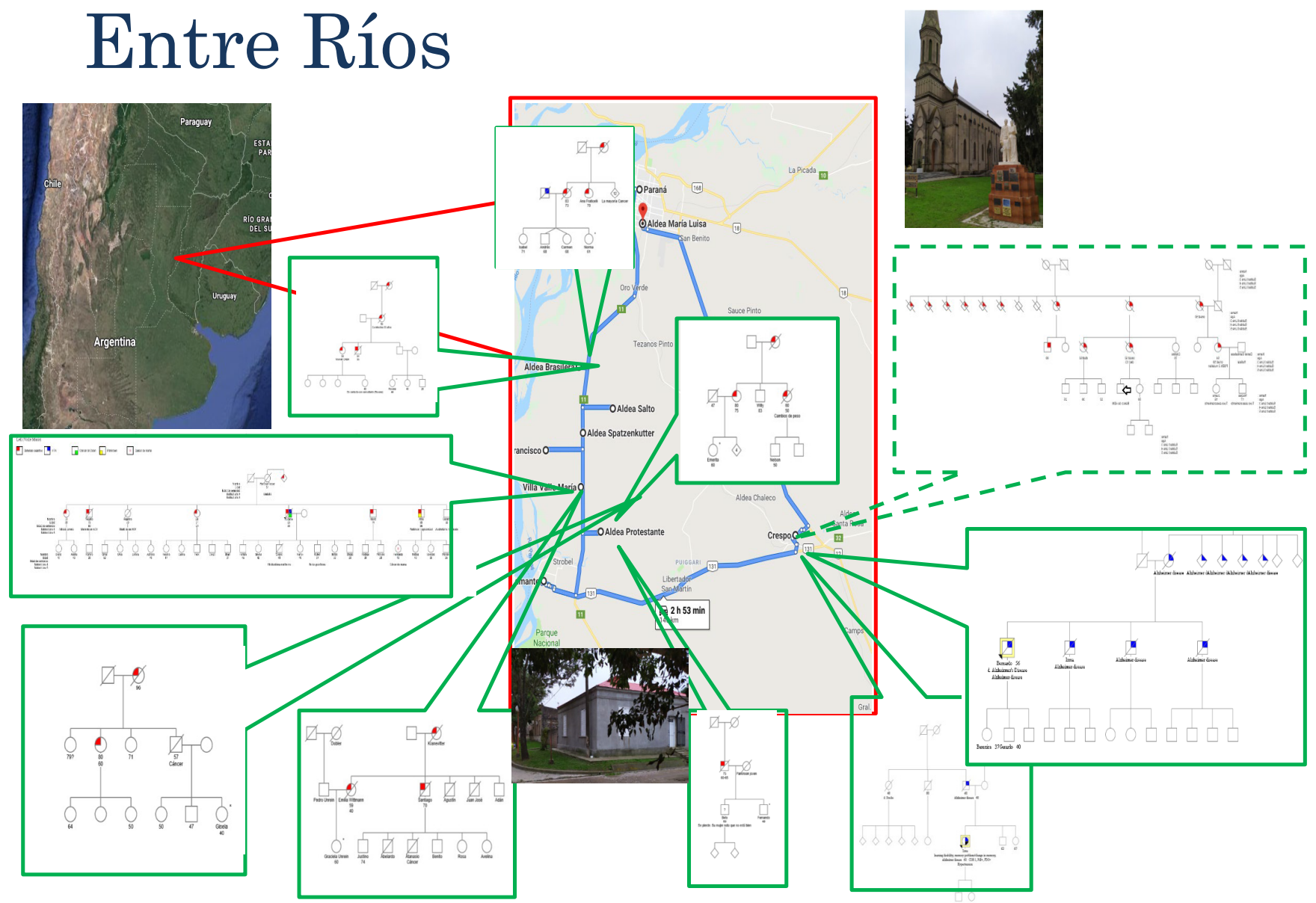

Figure 2. Route map of the fieldwork carried out for identifying possible familial cases within Volga-German communities in Entre Rios province (Argentina).

Source: Authors.

Volga-German communities in ARG (Calculated 500.000 inhabitants)

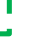


The greatest news for Argentinean families with ADAD occurred at the beginning of 2021 since the enrollment for the aforementioned arm IV of the TU in FLENI began. The first participant has already been enrolled and the rest of the "Obs" is expected to follow in its footsteps. Although the E2814 will not be available for testing before the end of 2021, the TU has begun with a cognitive pre-study (CRI of English; Cognitive Run-in) that guides the cognitive tests as they were receiving the drug. This way, it will be possible to enhance the statistical analysis when the active arm is tested and facilitate the incorporation and adherence of the participants to the study.

In conclusion, participating in the DIAN invites us to a unique experience: young patients and families mobilized in an early intervention study, where the most advanced knowledge in the field of genetics, biomarkers, and therapeutics with potentially disease-modifying drugs, converge. All this takes place in a dynamic of shocking human content, accompanying these families on a complex path, with a growing hope of being closer to the delay (or cure) of the disease.

\section{REFERENCES}

Aschenbrenner, A. J.; James, B. D.; McDade, E.; Wang, G.; Lim, Y. Y.; Benzinger, TLS.; Cruchaga, C.; Goate, A.; Xiong, C.; Perrin, R.; Buckles, V.; Allegri, R.; Berman, SB.; Chhatwal, JP.; Fagan, A.; Farlow, M.; O'Connor, A.; Ghetti, B.; Graff-Radford, N.; Goldman, J.; Gräber, S.; Karch, CM.; Lee, JH.; Levin, J.; Martins, R. N.; Masters, C.; Mori, H.; Noble, J.; Salloway, S.; Schofield, P.; Morris, J. C.; Bateman, R. J. \& Hassenstab, J. (2020). Awareness of genetic risk in the Dominantly Inherited Alzheimer Network (DIAN). Alzheimer's \& dementia: the journal of the Alzheimer's Association, 16(1), 219-228.

https://doi.org/10.1002/alz.12010

Bateman, R. J.; Xiong, C.; Benzinger, T. L.; Fagan, A. M.; Goate, A.; Fox, N. C.; Marcus, D. S.; Cairns, N. J.; Xie, X.; Blazey, T. M.; Holtzman, D. M.; Santacruz, A.; Buckles, V.; Oliver, A.; Moulder, K.; Aisen, P. S.; Ghetti, B.; Klunk, W. E.; McDade, E.; Martins, R. N.; Masters, C. L.; Mayeux, R.; Ringman, J. M.; Rossor, M. N.; Schofield, P. R.; Sperling, R. A.; Salloway, S. \& Morris, J. C. (2012). Clinical and biomarker changes in dominantly inherited Alzheimer's disease. The New England journal of medicine, 367(9), 795-804.

https://doi.org/10.1056/NEJMoa1202753

Bateman, R. J.; Aisen, P. S.; De Strooper, B.; Fox, N. C.; Lemere, C. A.; Ringman, J. M.; Salloway, S.; Sperling, R. A.; Windisch, M. \& Xiong, C. (2011). Autosomal-dominant Alzheimer's disease: A review and proposal for the prevention of Alzheimer's disease. Alzheimer's Research \& Therapy, 2(6), 1-11.

https://doi.org/10.1186/alzrt59

Bateman, R. J.; Benzinger, T. L.; Berry, S.; Clifford, D. B.; Fagan, A. M.; Fanning, K.; Farlow, M. R.; Hassenstab, J.; McDade, EM.; Mills, S.; Paumier, K.; Quintana, M.; Salloway, S. P.; Santacruz, A.; Schneider, L. S.; Wang, G. \& Xiong, C. (2017). The DIAN-TU Next Generation Alzheimer's prevention trial: Adaptive design and disease progression model. Alzheimer's \& dementia: the journal of the Alzheimer's Association, 13(1), 8-19. https://doi.org/10.1016/j.jalz.2016.07.005 
Libre-Guerra, J. J.; Li, Y.; Allegri, R. F.; Mendez, P. C.; Surace, E. I.; Llibre-Rodriguez, J. J.; Sosa, A. L.; Aláez-Verson, C.; Longoria, E. M.; Tellez, A.; Carrillo-Sánchez, K.; Flores-Lagunes, L. L.; Sánchez, V.; Takada, L. T.; Nitrini, R.; Ferreira-Frota, N. A.; Benevides-Lima, J.; Lopera, F.; Ramírez, L.; Jiménez-Velázquez, I.; Schenk, C.; Acosta, D.; Behrens, M. I.; Doering, M.; Ziegemeier, E.; Morris, J. C.; McDade, E. \& Bateman, R. J. (2020). Dominantly inherited Alzheimer disease: Frequency, genetic heterogeneity, and clinical phenotype in Latin America: Genetic heterogeneity and clinical phenotypes. Alzheimer's Dement, 16(S2), 653-664.

https://doi.org/10.1002/alz.044794

Morris, J. C.; Aisen, P. S.; Bateman, R. J.; Benzinger, T. L. S.; Cairns, N. J.; Fagan, A. M.; Ghetti, B.; Goate, A. M.; Holtzman, D. M.; Klunk, W. E.; McDade, E.; Marcus, D. S.; Martins, R. N.; Masters, C.L.; Mayeux, R.; Oliver, A.; Quaid, K.; Ringman, J. M.; Rossor, M. N.; Salloway, S.; Schofield, P. R.; Selsor, N. J.; Sperling, R. A.; Weiner, M. W.; Xiong, C.; Moulder, K. L. \& Buckles, Virginia D. (2012). Developing an international network for Alzheimer's research: the Dominantly Inherited Alzheimer Network. Clinical investigation (Lond), 2(10), 975-984. Available:

https://www.openaccessjournals.com/articles/developing-an-international-network-foralzheimers-research-the-dominantly-inherited-alzheimer-network.pdf

Rahman, B.; Meiser, B.; Sachdev, P.; Barlow-Stewart, K.; Otlowski, M.; Zilliacus, E. \& Schofield, P. (2012). To know or not to know: An update of the literature on the psychological and behavioral impact of genetic testing for Alzheimer disease risk. Genetic testing and molecular biomarkers, 16(8), 935-942.

https://doi.org/10.1089/gtmb.2011.0300 